\title{
ADEQUATE SUBSTRATE MOISTENING SYSTEM AND ARTIFICIAL LIGHTING FOR THE GROWTH OF HIGHER PLANTS IN THE "SVET" SPACE GREENHOUSE
}

\author{
P. T. KOSTOV, T. N. IVANOVA, S. M. SAPUNOVA
}

Space Research Institute, Sofia 1000, Bulgaria

Received April 18, 1995

Accepted June 6, 1996

\begin{abstract}
Kostov P. T., T. N. Ivanova, S. M. Sapunova: Adequate Substrate Moistening System and Artificial Lighting for the Growth of Higher Plants in the "Svet" Space Greenhouse. Acta vet. Brno 1996 65: 19-25.

The paper reports on some technical and technological problems that occurred during the „Substrate" space experiment conducted in 1985 and the "Svet" experiment conducted in 1990. This experience served as a basis for improvements of the systems for future use in space flights.

Some technical and technological problems had to be solved in the course of development of the Vegetation Module (VM) and Illumination Unit (IU) such as free motion of the substrate granules, process of self-cooling in the VM, insulation of the air space between VM and IU. The purpose of reported technical improvements of the system is to enhance plant productivity during future space flights.
\end{abstract}

Vegetation Module, Illumination Unit, plant, growth, biomass

After concluding agreements between Russian, American and Bulgarian specialists for continuation the research on higher plant growth in conditions of microgravity, the Bulgarian side undertook to provide a part of the units and equipment necessary for the new experiment. Two different sets of equipment will be delivered to the existing onboard the MIR Space Station "SVET" Space Greenhouse (SG) and two simultaneous experiments in Russia and USA will be conducted.

Some technical and technological problems which arose in the course of development of the Vegetation Module (VM) and Illumination Unit (IU) which provide conditions of vital importance for plant growth such as the root system moistening and biomass lighting will be considered in this paper.

Table 1

Content of nutritives and microelements in the mineral substrate „Balkanine“

\begin{tabular}{|c|c|}
\hline Nutritives & $(\%)$ \\
\hline $\mathrm{N}$ & $0,15-0,20$ \\
\hline $\mathrm{P}_{2} \mathrm{O}_{5}$ & $0,04-0,12$ \\
\hline $\mathrm{K}_{2} \mathrm{O}$ & $3,5-4$ \\
\hline $\mathrm{CaO}$ & $1,8-2,1$ \\
\hline $\mathrm{MgO}$ & $0,9-1,0$ \\
\hline $\mathrm{Fe}_{2} \mathrm{O}_{3}$ & $1,2-1,5$ \\
\hline $\mathrm{m}$ & $0,18-0,20$ \\
\hline
\end{tabular}

\begin{tabular}{|c|c|}
\hline Microelements & (ppm) \\
\hline $\mathrm{B}$ & $2,0-4,0$ \\
\hline $\mathrm{Cu}$ & $15-20$ \\
\hline $\mathrm{Zn}$ & $40-80$ \\
\hline
\end{tabular}




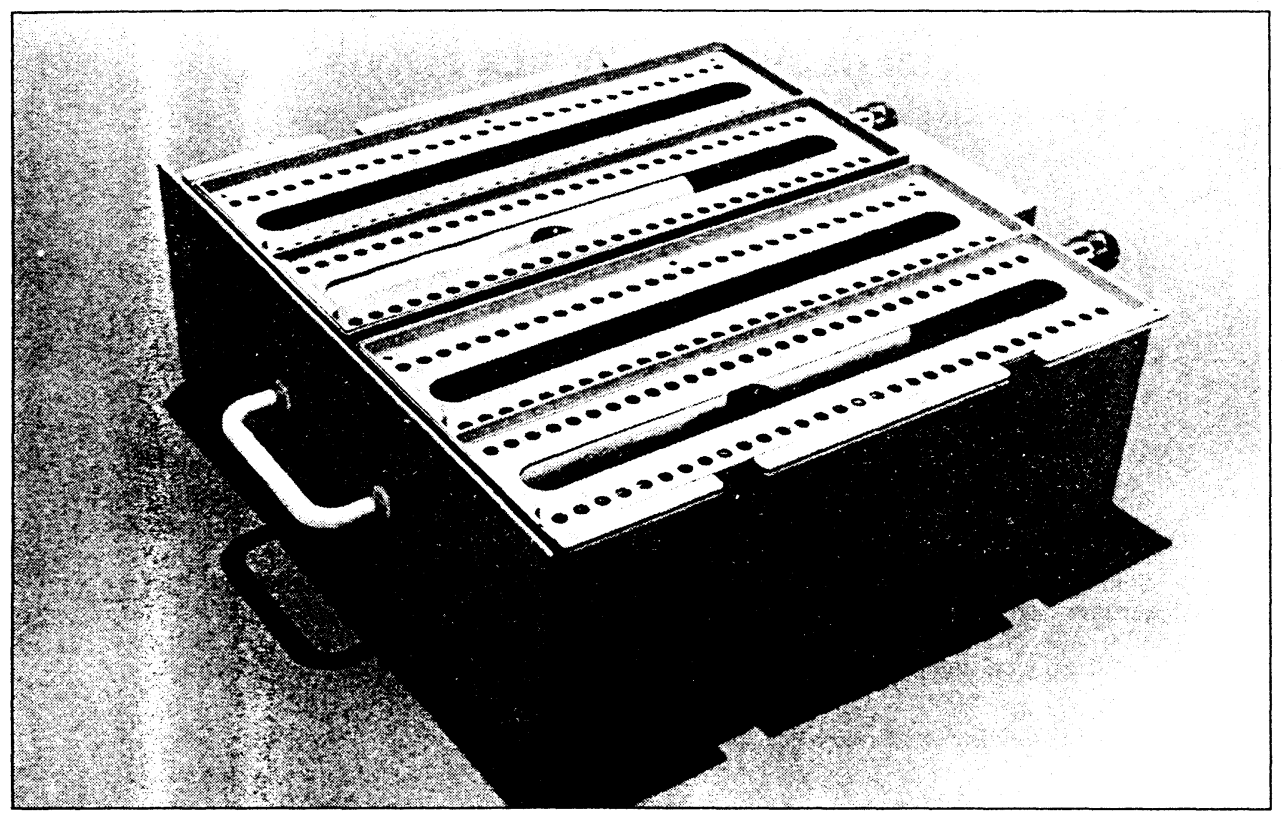

Fig. 1. Appearance of the Vegetation Module (VM) in "SVET" Space Greenhouse

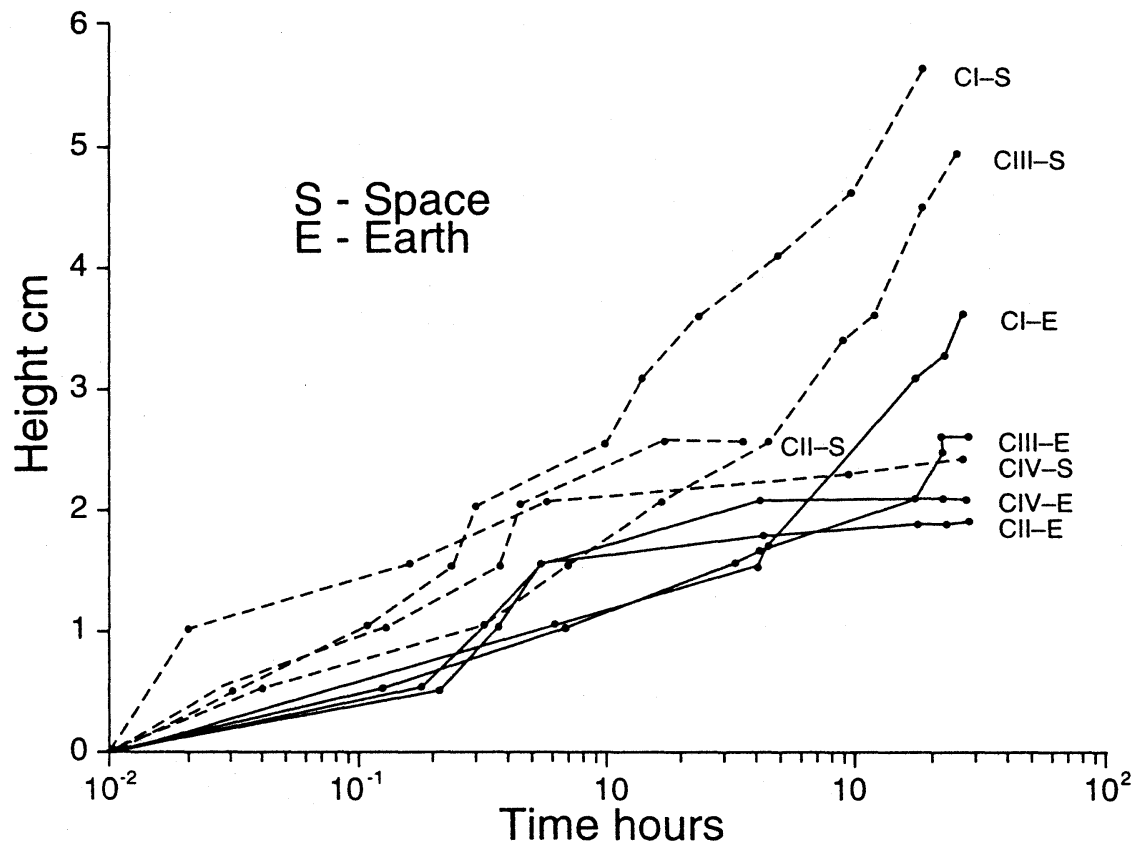

Fig. 2. Experiment "Substrate" - substrate moistening characteristics (fractions $\mathrm{CI}=1-1.5 \mathrm{~mm}$; $\mathrm{CII}=1.5-2.5 \mathrm{~mm}$; CIII $=2.5-3.25 \mathrm{~mm}$; CIV-composite) in the Space (S) and on Earth (E) experiments 


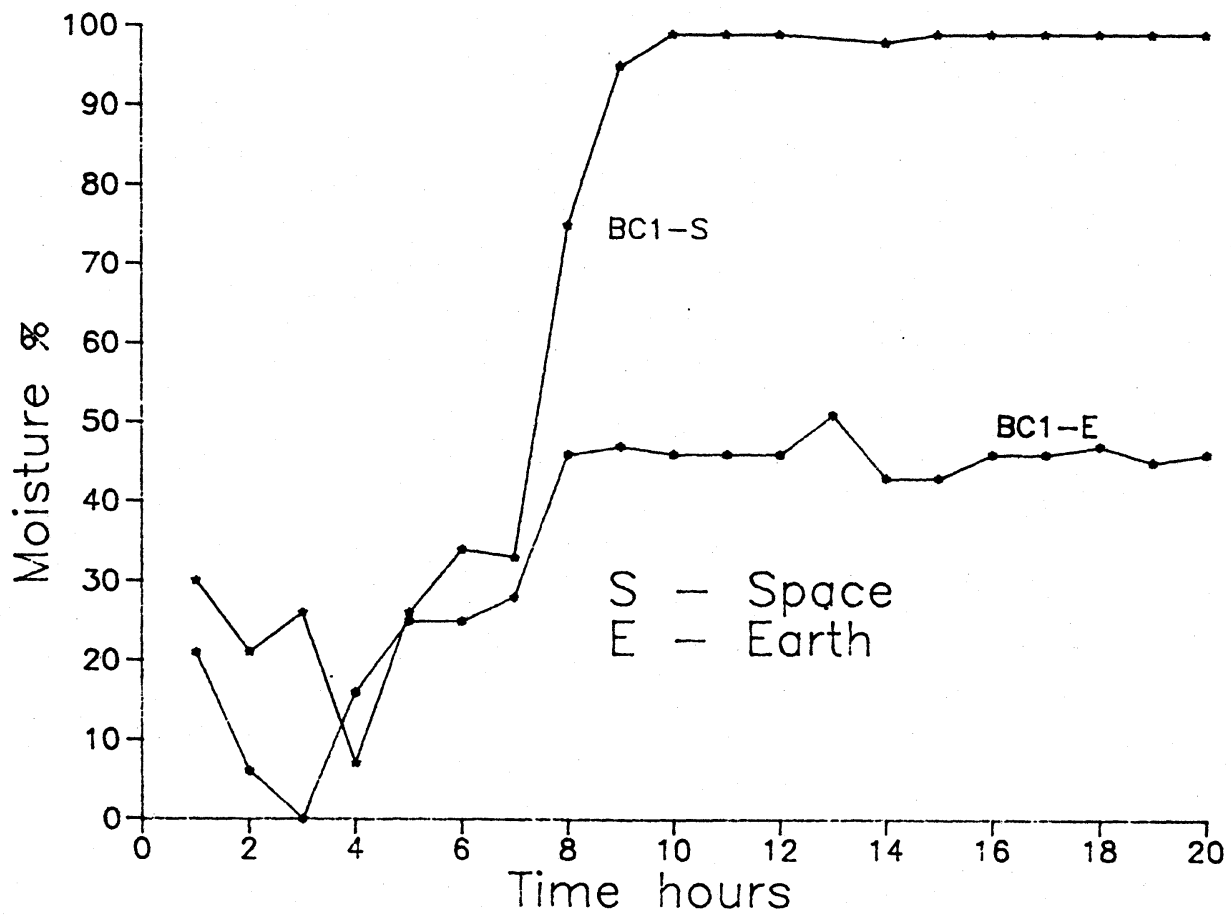

Fig. 3. The substrate moistening (BC1) in VM during the first 20 hours of the experiment "SVET" Greenhouse in 1990

\section{Materials and Methods}

The Vegetation Module is one of the most important units in the "SVET" SG. Its flight copy was developed after multiple theoretical and experimental checking-up of each detail. The VM appearance is shown in Fig. 1. The two halfcassettes are not made water and air-proof. An aerosystem, systems for supply, accumulation and spread of water as well as a substrate moisture sensor in each of them are installed. All the rest space is filled with substrate "BALKANINE" which is natural granulated zeolite dressed with nutritives. The content of nutritives is given in Table 1. Radish and cabbage during the period June-August 1990 were grown in the "SVET" SG (Iv a n o v a and Dandolov 1992).

The analysis of the spread of water characteristics in the substrate which is the basis for the gas-liquid supply of the plant root zone in conditions of microgravity were already reported (I v a n o $\mathrm{va}$ and Ko s to $\mathrm{v} \mathrm{1986).}$

In order to trace back the chronology of the problem for water providing the substrate we would like to mention the result of the experiment "SUBSTRATE" conducted onboard the SALYUT-7 orbital station in 1985. The water movement rates in the substrate of four different fractions on board and simultaneously on Earth were measured. It is evident from Fig. 2 that most similar characteristics of the water conduct in the fourth container with mixture of all the fractions in it can be observed. This result as well as the other air-liquid characteristics defined the real granularity of the substrate in this cassette. Hydroaccumulators and wicks for accelerated water movement were supplemented to increase the total blotting capacity of the nutritions environment for the plants. We expected a difference of $10-20 \%$ in the water conduct in the synchronous experiments onboard and on Earth to turn out.

The dynamics of moistening in this composite heterogeneous environment in the cassette in Fig. 3 (I va n o va et al. 1992) is shown. A comparison between the curves shows that the substrate moistening in the zone next to the wick runs slowly in conditions of microgravity.

We will quote the conclusion drawn in (Podols ky et al. 1991): Probably, in microgravity conditions, a local overmoistured zone around the wicks in cells is formed, while the main volume of Balkanine, the mineral food carrier, has low moisture level. The existence of water distribution in cells, could also lead to mineral supply storage and consequently to plant growth slowing down. We can add that the $99 \%$ readings of the moisture sensor are due to water penetration to the sensor through a multilayer wick. 


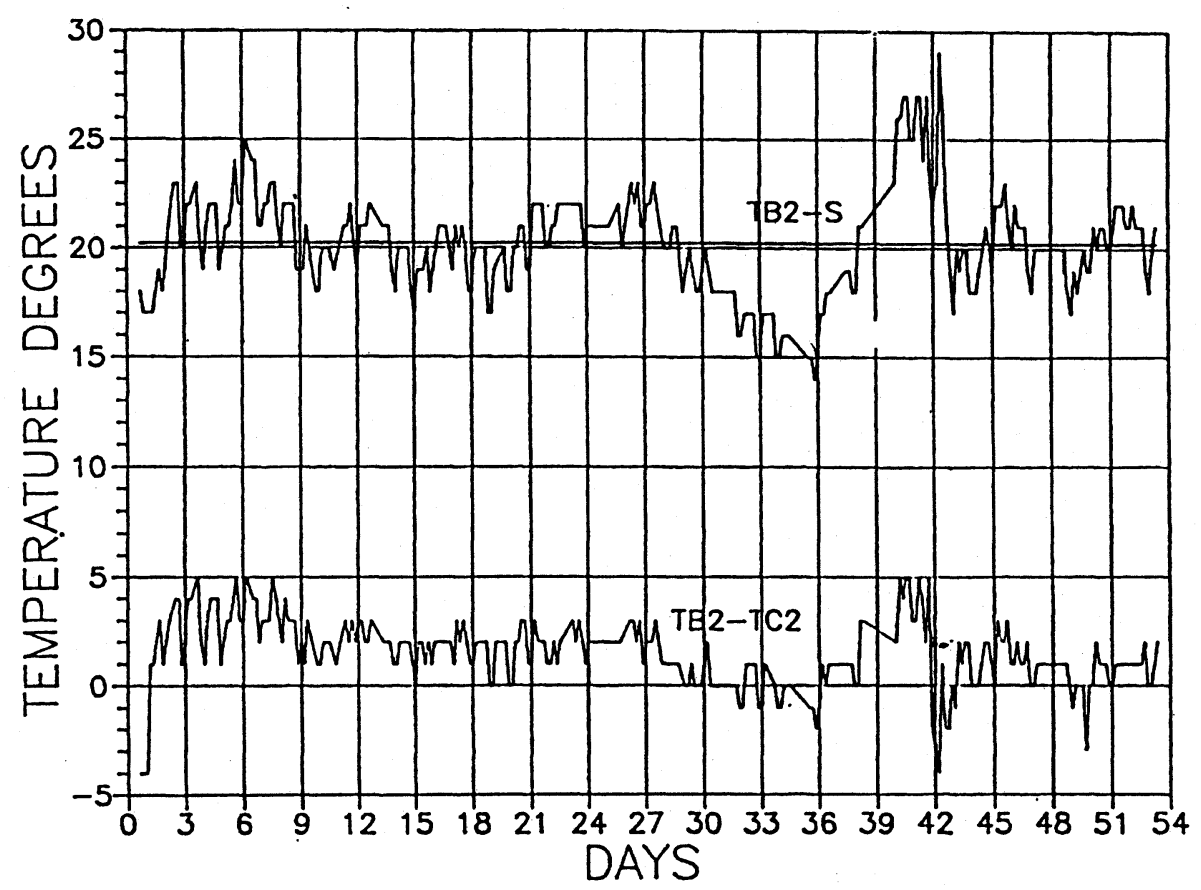

Fig. 4. Plants chamber air temperature (TB2) and temperature difference air-substrate (TB2-TC2) during 53 days space experiment with "SVET" in 1990

The Bulgarian makers of "SVET" SG as a basic module consider that bringing of the new American equipment in (B in g h a m et al. 1994) will influence negatively the "SVET" microclimate as a whole. For that reason we decided to give some recommendations about equipment compatibility and to suggest some alterations in the changeable units of VM.

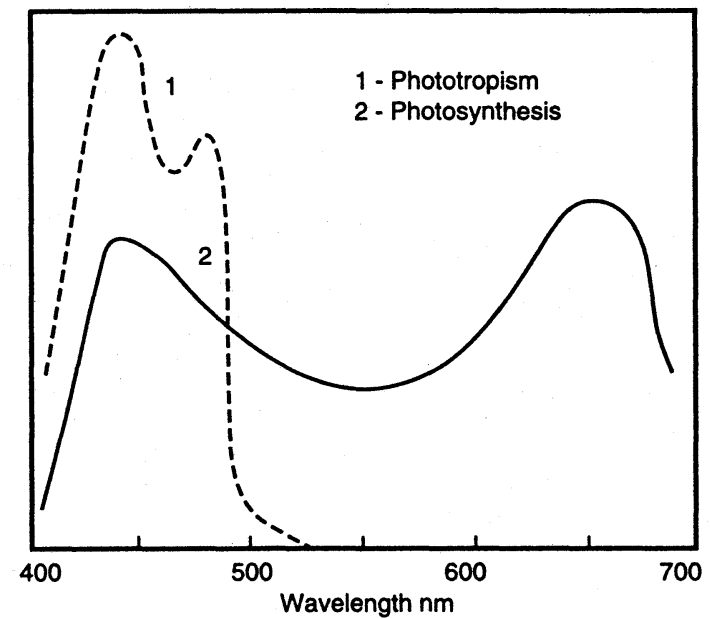

Fig. 5. Activity of some physiological processes - phototropism (1) and photosynthesis (2) depending on the effect of light of different wave length 

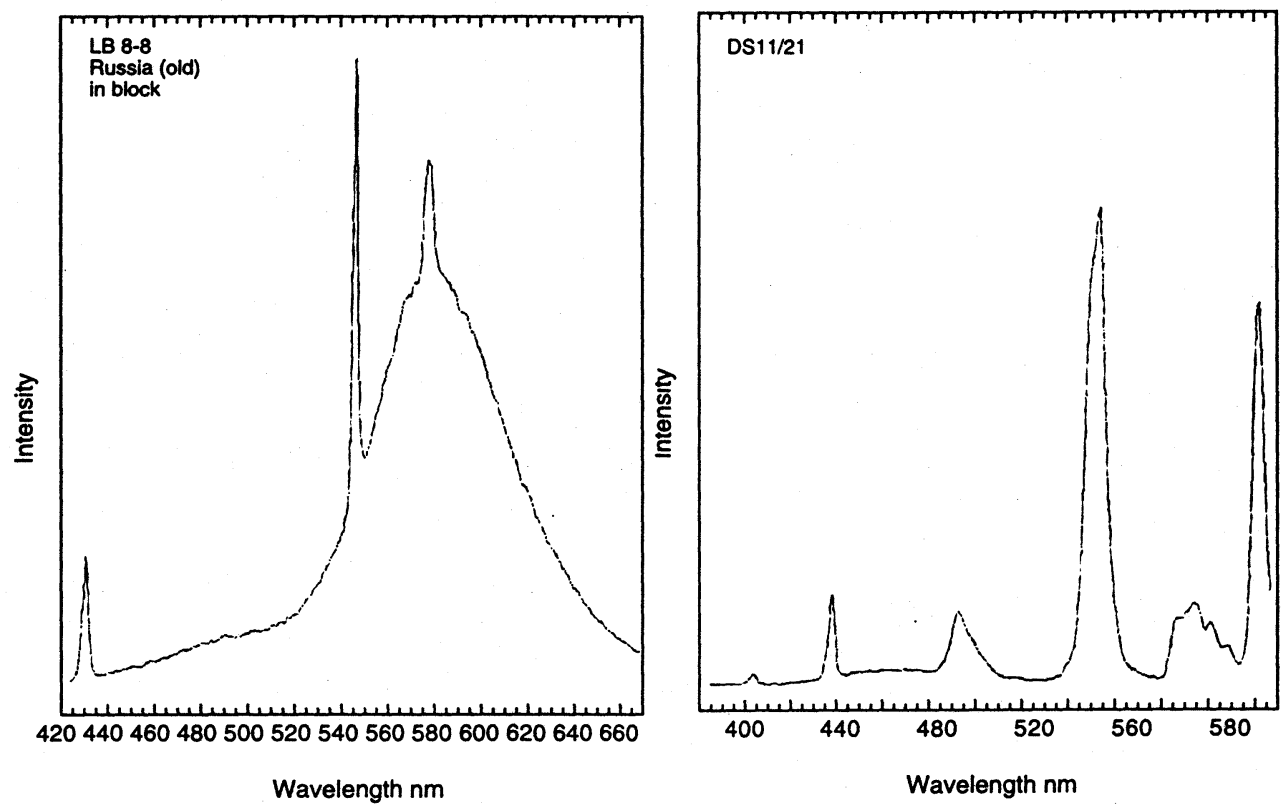

Fig. 6. Spectral-response characteristics of the Russian lamps LB 8-6 used in the experiments with "SVET" in 1990 Fig. 7. Spectral-response characteristic of the fluorescent lamps DS 11/21 of OSRAM to be used in the Illumination Unit (IU) in future experiments with "SVET" Space Greenhouse

\section{Results and Discussion}

Apparently the moisture distribution in the compound environment within VM is not easily subjected to theoretical analysis. New substrate moisture sensors will be located in different points of the cassette. In this way volumetric moisture distribution in this cassette will be obtained. As the primary sensor remains and only this one is connected with the "SVET" SG processor control system, we suggest:

1. To reduce the connection between the sensor and hydroaccumulator either varying the width of the wick, or lowering the wick in the substrate beside the hydroaccumulator. We expect that in such conditions the wick will create its own moistured area around the sensor as the water will move from the hydroaccumulator to the wick passing trough a layer of substrate. In this way the sensor will register the moisture really passed through the substrate.

2. It is probable that free motion of the granules especially for the small fractions in weightlessness will occur. Such phenomenon was observed during the experiment "SUBSTRATE" by the cosmonauts despite the fact that on Earth the granules remained firm. This fact creates preconditions for the capillary bonds in different layers of the substrate to be disconnected.

Our observations on the mechanical properties of the substrate after initial moistening and subsequent drying without spilling it out of the cassette showed that the dry substrate volume conducted itself as a united whole with typical granulous structure and empty spaces between the granules.

We suggest cassettes already processed with known residual moisture in the volume to be delivered on board. Such a Vegetation Module will possess a number of advantages: stability in transportation, minimum components of dust out of the cassette after transporting, 
increased possibility to keep the capillary bonds, better calibration accuracy of the sensors measuring substrate moisture (without changing fittings). At the same time one disadvantage should be pointed out - heigher weight of the substrate as a result of the residual moisture in the cassette after imperfect drying.

3. Process of self-cooling in the VM. The physiologists have always maintained that to ensure a process of normal higher plants growth the temperature in the root area TC2 (in the substrate) should be lower than the one in the leaves zone TB2 (in the air). The Plant Growth Unit (PGU) and VM are designed in such a way, that the air entering down the PGU streams $\mathrm{VM}$ and maintains a continuous slow process of water vaporizing from the substrate trough a number of perforations. How far it is efficient when the continuous experiment "SVET" in 1990 was conducted is shown in the following two curves (Fig. 4) (Ivanova et al. 1994). A difference of $2-4^{\circ} \mathrm{C}$ between the temperatures TB2 and TC 2 is kept during the succession day - night as well as the whole period of growth.

Full isolation of the air space between VM and IU by means of biax and nylon bags and clear lexan cover is foreseen in the new experiment. Furthermore, the glasses will be taken off the windows. We expect that the air flow created by the ventilator will completely change its direction - down below VM the air flow will diminish and substrate cooling will get worse. On the other hand the lamp cooling will be unilateral and ineffective, too. We propose after planting work within the PGU, the window to be closed again, the bag ceiling to be put 1-2 cm away from IU and to keep track of the gas pressure so that the nylon would not press close to the PGU walls.

The Illumination Unit is the biggest energy consumer within the "SVET" SG. We hope that light-conducting tubes for effective using the sunlight will be constructed before long.

The plants need light with determined quantity and quality. Photophysiological data show that the plants consume energy mostly in two spectral bands - blue and red. In a space biological experiment conducted under microgravity conditions it is necessary to ensure minimum living conditions for the plants relevant to the photosynthesis and phototrophism (Fig. 5). Till the experiment in 1990 we used fluorescent lamps LB 8-6 (12 pieces). The spectral response characteristic of IU is shown in Fig. 6. It is seen that almost the whole luminous energy is concentrated in minimum sensibility zone of the plants. That considerable discrepancy between the light source and plant needs was due to the lack of special lamps with appropriate characteristics during the period of development.

The increased supply of fluorescent lamps in the last years gave a possibility to conduct an extensive research on the characteristics of various kinds of lamps. The spectral-response characteristics of 12 kinds of lamps in the band $400-600 \mathrm{~nm}$ were taken with the help of the Faculty of Physics at Sofia University. For some of them the measuring range in the blue and red region, respectively, was enlarged. The energy characteristics are of particular importance when put to use onboard. The geometrical dimensions of IU narrow the range of the used lamps, too. The fluorescent lamp DS11W/21 of OSRAM was chosen as the most suitable one for our aim (Fig. 7).

In connection with building of the illuminant two more important investigations were conducted - on a white reflecting paint, made to order, suiting very special requirements, and on a transparency coefficient of the plexiglass for proofing the separate illuminants. As a result of investigations considerably improved brightness characteristics of the developed IU were received - at a distance of $15 \mathrm{~cm}$ from the illuminants the intensity was 27000 lux (under 12000 in 1990). Adding the lamp spectrum suitable for intensive photosynthesis, as well as its large warranted duration of work ( 8000 hours) we can expect considerable increase of the plant productivity (quantity of biomass) in the future experiments.

Work on preparation for series of biological experiments for growing of higher plants in 
the conditions of greenhouse with a new IU without using fluorescent lamps has been started. The light emission will be focused in narrow spectral bands only corresponding to the highest requirements of the plants.

The expected coming extension of the Bulgarian participation in biological space experiments gives us reason to prepare a new inclusive programme for biological and technical researches in the Space Research Institute for Plant Physiology.

\section{Vplyv adekvátneho zvlhčovania substrátu a umelého osvetlenia na zvýšenie rastu rastlín vo vesmírnom skleníku ,svet“"}

Diskutuje sa o technických a technologických problémoch, ktoré vznikli ako výsledok získaných skúseností po uskutočnení experimentu „SUBSTRATE“ v r. 1985 a experimentu „SVET“v r. 1990. Pre zvýŠenie produktivity rastlín počas nového experimentu v programe MIR-SHUTTLE-95 boli určené niektoré odporúčania, týkajúce sa charakteristík Vegetačného modulu a OsvetTovacej jednotky.

\section{Влияние адекватного увлажнения субстрата и искусственного освещения на интенсивность роста растений в космической теплице „СВЕТ *}

Идут обсуждения технических и технологических проблем, возникших на основе полученного опыта реализации в 1985 г. эксперимента "СУБСТРАТ “ и в 1990 г. эксперимента "СВЕТ “. С целью увеличения продуктивности растений во время нового эксперимента по программе MIRSHUTTLE-95 были сформулированы некоторые рекомендации, касающиеся характеристик Модуля вегетации и Блока освещения.

\section{References}

BINGHAM, G. E., SALISBURY, F. B., CAMPBELL, W. F., CARMAN, J. G., BUBENHEIM, D. I., YENDLER, B., SYTCHEV, V. N., BERKOVICH, Yu. A., LEVINSKIKH, M. A., PODOLSKY, I. G. 1994: Proc. 30th Meet. COSPAR. Hamburg, Germany

IVANOVA, T. N.,BERKOVICH, Yu. A., MASHINSKY, A. L., MELESHKO, G. I. 1992: Microgravity Q, 2:109114

IVANOVA, T. N., DANDOLOV, I. W. 1992: Microgravity Sci. technol. 3:151-155

IVANOVA, T. N., KOSTOV, P. T. 1986:IAF/IAA-86-374

IVANOVA, T. N., SAPUNOVA, S. M., DANDOLOV, I., IVANOV, Y., MELESHKO, G. I., MASHINSKI, A., BERKOVICH, Yu. A. 1994: Adv. Space Res. 14:(II)343-(II)346

PODOLSKY, I. G., MASHINSKY, A. L., BERKOVICH, Zu. A., IVANOVA, T. N. 1991: Second microsymposium „Svet-90“, pp. 47-56 